\title{
Catabolism and synovial transport of rheumatoid factor
}

\author{
R. BLUESTONE, A. CRACCHiolo, III, L. S. GOLDBERG, and C. M. PEARSON \\ From the Department of Medicine, University of California School of Medicine, Los Angeles, California 90024
}

Antiglobulins or rheumatoid factors (RF) are found in the sera and synovial fluids of most patients with rheumatoid arthritis (Vaughan and Butler, 1962; Rodnan, Eisenbeis, and Creighton, 1963). When the serum and synovial fluid from the same patient are compared, the titre of RF is usually higher in serum, but remarkably higher titres are occasionally present in synovial fluid, suggesting that both systemic and synovial immune systems contribute to the body's pool of RF (Bland and Clark, 1963; Hannestad and Mellbye, 1967). However, the use of comparative titres to indicate the site of RF production does not take into account serum-synovial transport mechanisms. The normal synovium is permeable to a variety of low molecular weight proteins (Mackiewicz and Fenrych, 1961; Schur and Sandson, 1963), and several dynamic studies have shown that radiolabelled albumin and IgG readily traverse the inflamed synovial membrane (Ahlström, Gedda, and Hedberg, 1956; Rodnan and Maclachlan, 1960). The only previous investigation on serum-synovial transport of a high molecular weight protein in rheumatoid arthritis was performed with a radio-labelled IgM cold agglutinin (Brown, Cooper, and Bluestone, 1968). After intravenous administration, the IgM readily crossed the rheumatoid synovium, and reached and maintained a dynamic equilibrium between plasma and synovial fluid. Moreover, the IgM entered the joint space more slowly than labelled albumin, although the rate of exit into plasma was the same for both proteins. Those results primarily reflected the role of molecular size on synovial transport. An IgM possessing antiglobulin activity, however, may not behave in the same manner as an IgM which is inert at body temperature; its distribution and transport could be influenced by antigen-antibody complex formation, and whether or not such complexes continue to circulate or are sequestered by the reticulo-endothelial system or elsewhere (Benacerraf, Sebestyen, and Cooper, 1959). The present investigation was undertaken to study the catabolism and serum-synovial transport of a purified antiglobulin in patients with inflammatory joint disease.

\section{Methods}

Purification, Characterization, and Labelling of $R F$

ISOLATION AND CHARACTERIZATION OF CRYOGLOBULIN

$30 \mathrm{ml}$. serum from a patient with mixed (IgG-IgM) cryoglobulinaemia was refrigerated at $4^{\circ} \mathrm{C}$. for $48 \mathrm{hrs}$. After centrifugation at $4^{\circ} \mathrm{C}$., the supernatant was removed and the cryoprecipitate redissolved at $37^{\circ} \mathrm{C}$. in phosphate buffered saline, $\mathrm{pH} 7 \cdot 0$. Material which failed to redissolve was discarded and the clear supernatant was kept at $4^{\circ} \mathrm{C}$. for $48 \mathrm{hrs}$. The resulting cryoglobulin was centrifuged at $4^{\circ} \mathrm{C}$. and washed in $20 \mathrm{ml}$. chilled phosphate buffered saline, $\mathrm{pH} \mathrm{7.0;}$; this cycle was repeated five times.

The components of the washed, redissolved cryoglobulin were identified in agar gel double diffusion using antisera monospecific for IgM, IgG, IgA, kappa and lambda light chains.* Antiglobulin activity was determined at $37^{\circ} \mathrm{C}$., using latex particles coated with human aggregated gammaglobulin, human type $O$ positive erythrocytes sensitized with anti-CD serum Ripley, and sheep red cells sensitized with rabbit gammaglobulin.

ISOLATION AND CHARACTERIZATION OF RHEUMATOID FACTOR

The cryoglobulin was redissolved at $37^{\circ} \mathrm{C}$. in each of three buffers: $0.15 \mathrm{M}$ sodium phosphate, $\mathrm{pH} 7.35 ; 0.2 \mathrm{M}$ sodium acetate-acetic acid, $\mathrm{pH} 4 \cdot 6$; and $1 \cdot 0 \mathrm{M}$ glycine$\mathrm{HCl}$, pH 3.0. Gel filtration was performed at room temperature over Sephadex G-200 columns; appropriate buffers were used as the eluents at flow rates of $10 \mathrm{ml}$. per hour. The integrity of each column had been previously shown by its ability to separate a mixture of dextran and albumin. Eluted peaks, measured spectrophotometrically

Reprint requests should be addressed to Dr. L. S. Goldberg, Department of Medicine, UCLA Medical Center, Los Angeles, California 90024 U.S.A. 
at $280 \mathrm{~m} \mu$, were dialysed against distilled water and concentrated by vacuum dialysis. Protein concentration was determined by the method of Lowry, Rosebrough, Farr, and Randall (1951), and the immunoglobulins present in each peak were detected by agar gel double diffusion, using monospecific antisera. Immunoglobulin concentrations were determined by radial diffusion in agar-antibody plates $†$ and, in some instances, by the method of quantitative complement-fixation (Wasserman and Levine, 1961; Goldberg and Barnett, 1967). Antiglobulin activities were measured at $37^{\circ} \mathrm{C}$. and antinuclear antibody activity was detected by a double-layer technique using human leucocytes and fluorescein conjugated to antisera $\ddagger$ monospecific for IgG, IgA, and IgM (Condemi, Barnett, Atwater, Jacox, Mongan, and Vaughan, 1965).

\section{LABELLING OF RHEUMATOID FACTOR}

The isolated IgM was labelled with ${ }^{125}$ I by McFarlane's method (1963), with the modifications of Helmkamp, Contreras, and Bale (1967), to give a final activity of 50 $\mu \mathrm{c} . / \mathrm{mg}$. IgM. Normal human albumin was added to prevent damage due to irradiation; 98 per cent. of the label was precipitated by the addition of trichloracetic acid (TCA). To confirm labelling of the IgM, $0.1 \mathrm{ml}$. radio-iodinated IgM solution was added to $0.9 \mathrm{ml}$. normal whole human serum; the mixture was subjected to Sephadex G-200 gel filtration, and the eluted peaks were tested for radioactivity content in a well-type gamma counter. $\S$ The labelled IgM preparation was also tested by radioimmunodiffusion, using antisera monospecific for IgG, IgA, IgM, kappa and lambda light chains, and by radioimmunoelectrophoresis against antiserum to whole human serum. Precipitin lines formed in 12 to $16 \mathrm{hrs}$ and the agar slides were washed in phosphate buffered saline, pH $7 \cdot 0$, for $36 \mathrm{hrs}$ with three changes of wash; the slides were dried on filter paper and placed agar-side down on No-screen $x$-ray film.|| Films were developed at 6 hrs.

\section{ANTIBODY ACTIVITY OF LABELLED RF}

Rheumatoid factor and antinuclear assays were performed as already described. Cryoprecipitability of the labelled IgM was tested by adding excess normal human IgG and leaving the mixture at $4^{\circ} \mathrm{C}$. for $12 \mathrm{hrs}$. The mixture was centrifuged at $4^{\circ} \mathrm{C}$., the supernatant and cryoprecipitate separated, and each counted for radioactivity. Labelled IgM, without added IgG, was tested simultaneously as a control.

\section{Patient Studies}

\section{PATIENT MATERIAL}

Five patients with gross knee joint effusions and one normal control subject were studied. Three patients had widespread sero-positive erosive rheumatoid arthritis, one had sero-negative psoriatic arthropathy, and one a chronic traumatic effusion. Rheumatoid factor titres and immunoglobulin levels were measured in the sera and synovial fluids of all five patients and in the serum from

\footnotetext{
†Hyland Laboratories, Los Angeles, California.

†Behringwerke Diagnostic Reagents, Woodbury, New York. \&Nuclear Chicago, Chicago, Illinois.

IIKodak, Rochester, New York.
}

the normal subject. All ingested $60 \mathrm{mg}$. potassium iodide daily for 3 days before and during the study.

\section{PLASMA-SYNOVIAL FLUID TRANSPORT}

For the first part of the study, each subject received 0.35 to $0.50 \mathrm{mg}$. ${ }^{125} \mathrm{I}$-labelled IgM (16 to $22 \mu \mathrm{c}$.) intravenously. Serial blood and $2 \mathrm{ml}$. synovial fluid samples from one or both knee joints were obtained at 15, 30, and $60 \mathrm{~min}$. and at approximately $2,4,8,24,36,48,60,72,96,120,168$, 216, and 264 hrs after administration.

\section{SYNOVIAL FLUID-PLASMA TRANSPORT}

When the plasma and synovial fluid specific activities from the first part of the study had fallen to insignificant levels, four patients (three with rheumatoid arthritis and one with psoriatic arthropathy) were given $0.5 \mathrm{mg}$. labelled IgM into the left knee joint. Samples were taken from that joint at $30 \mathrm{~min}$. and at 8,24 , and $72 \mathrm{hrs}$ after injection. Blood and synovial fluid samples from the right (noninjected) knee were taken at 30 and $60 \mathrm{~min}$. and at approximately $2,4,8,24,60$, and 72 hrs.

\section{SAMPLE RADIOACTIVITY CONTENT}

Radioactivity was counted in $1 \mathrm{ml}$. aliquots of each sample. Alternate specimens were mixed with $0.1 \mathrm{ml}$. of normal rabbit serum and $1.1 \mathrm{ml}$. of 20 per cent. TCA. The resulting precipitates were centrifuged and washed and their radioactivity content was determined. For the plasma to synovial fluid transport study, the radioactivity in each sample was expressed as a percentage of the radioactivity present in the $15-\mathrm{min}$. plasma sample. For the synovial fluid to plasma transport study, the radioactivity in each sample was expressed as a percentage of the radioactivity present in the $30 \mathrm{~min}$. injected-joint sample. Specific activities were plotted on semilogarithmic graph paper against time.

\section{AUTORADIOGRAPHY}

On the fourth day after the intra-articular injection of the labelled IgM, autoradiographic studies were performed on the synovial membrane obtained at synovectomy from the injected knee of one of the rheumatoid patients (Case 3). The tissue was immediately frozen in liquid nitrogen and sections, 2 to $4 \mu$, were prepared on a cryostat at $-20^{\circ} \mathrm{C}$. The sections were fixed onto gelatin-coated slides with absolute methanol. AR-10 $x$-ray film|| was then layered over the tissue and the films developed after 10 to 14 days at $4^{\circ} \mathrm{C}$. The tissue was stained using a modified Giemsa technique (Feinendegen and Bond, 1962).

\section{Results}

\section{CRYOGLOBULIN CHARACTERIZATION}

The re-dissolved washed cryoglobulin consisted of IgG and IgM immunoglobulins. At a concentration of $1 \mathrm{mg} . / \mathrm{ml}$., the cryoglobulin had a latex-agglutination titre of $1: 320$ and a titre of $1: 160$ when tested 
against Ripley sensitized red cells. It failed to agglutinate sensitized sheep cells.

\section{ISOLATION AND CHARACTERIZATION OF RF}

G-200 gel filtration of the cryoglobulin in $0.15 \mathrm{M}$ sodium phosphate buffer, $\mathrm{pH} 7 \cdot 35$, failed to separate the IgG and IgM components; one large peak containing IgG and IgM was eluted in the void volume. When $0 \cdot 2 \mathrm{M}$ acetate buffer, $\mathrm{pH} 4 \cdot 6$, was used as the eluent, two peaks were obtained (Fig. 1). The second peak consisted of IgG only, but the peak eluted in the void volume again contained both IgG and IgM, indicating an incomplete separation. This latter peak was re-chromatographed using $1.0 \mathrm{M}$ glycine- $\mathrm{HCl}$, $\mathrm{pH} 3 \cdot 0$, and the peak emerging in the void volume, at a concentration of $0.83 \mathrm{mg} . / \mathrm{ml}$., contained only IgM with kappa type light chains when tested by agar gel double diffusion. This peak contained $2 \cdot 1$

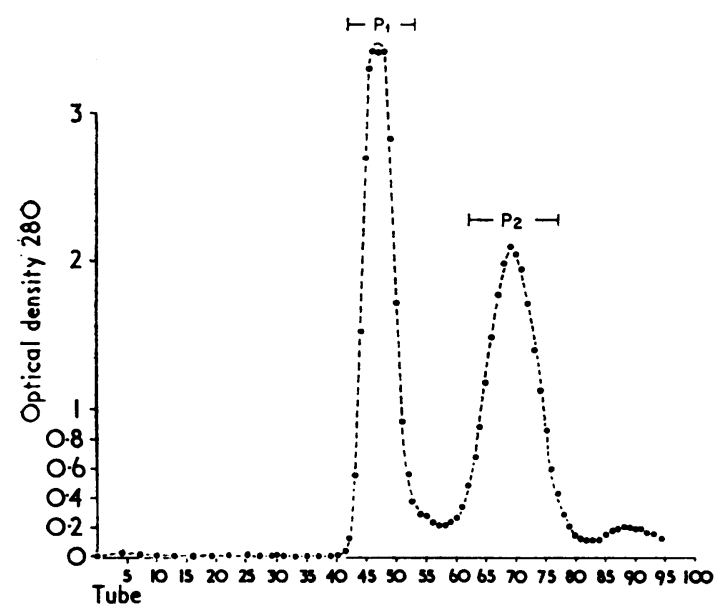

FIG. 1 Sephadex G-200 gel filtration of the mixed (IgGIgM) cryoglobulin at $\mathrm{pH} 4 \cdot 6$. The peak eluted in the void volume $\left(P_{1}\right)$ contained IgM and IgG. The second peak $\left(P_{2}\right)$ consisted of only IgG. $\mu \mathrm{g}$. IgG $/ \mathrm{ml}$. and no detectable IgA when tested by the method of quantitative complement fixation (in the complement-fixation test, IgA levels of less than $4 \mu \mathrm{g}$. $/ \mathrm{ml}$. could not be detected).

\section{ANTIBODY ACTIVITY OF THE PURIFIED IgM}

The initial peak eluted at $\mathrm{pH} 4 \cdot 6$, which had a protein concentration of $1 \mathrm{mg}$./ml., gave a latex-agglutination titre of $1: 1,280$ and a titre of $1: 128$ when tested against Ripley sensitized red cells. The purified IgM $(0.83 \mathrm{mg} . / \mathrm{ml}$.) obtained by gel filtration at $\mathrm{pH} 3.0$ had a latex-agglutination titre of $1: 10,240$. After labelling, the IgM $(0.6 \mathrm{mg} . / \mathrm{ml}$.) gave a latex titre of $1: 1,280$. Sheep cell agglutination tests were negative. Both the labelled and unlabelled IgM specimens showed a 2 plus speckled pattern when tested for antinuclear antibody with fluorescein conjugated antiserum to IgM. Addition of excess IgG to the labelled IgM and exposure of the mixture at $4^{\circ} \mathrm{C}$. for $12 \mathrm{hrs}$ resulted in precipitation of 80 per cent. of the radioactive counts. Exposure of the IgM solution alone at $4^{\circ} \mathrm{C}$. failed to produce a cryoprecipitate.

\section{SPECIFICITY OF LABELLING}

When the labelled IgM solution was mixed with normal whole serum and subjected to Sephadex G-200 gel filtration, all radioactivity emerged in the void volume associated with the high molecular weight proteins. Precipitin lines formed at $16 \mathrm{hrs}$ when the labelled IgM was diffused in agar gel against antisera to IgM and to kappa light chains; no lines appeared with the antisera to $\operatorname{IgG}, \operatorname{IgA}$, or lambda light chains. The precipitin lines were shown to be radioactive and formed a pattern of complete identity on autoradiography (Fig. 2). When the labelled IgM was examined by radioimmunoelectrophoresis, an IgM and an albumin arc were produced. Only the former was radioactive.

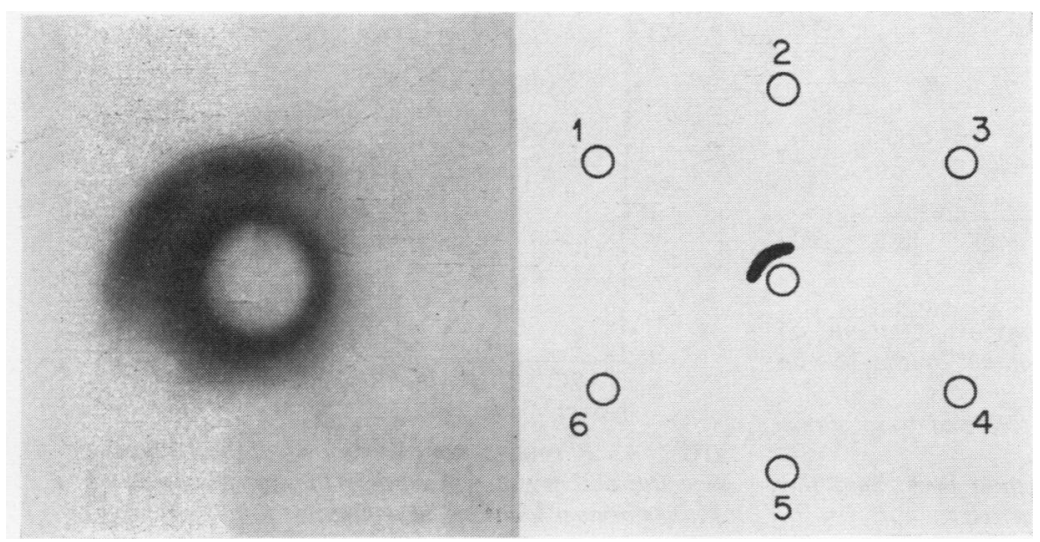

FIG. 2 Radioautograph of immunodiffusion plate. Centre well contained 125 I-labelled IgM, and peripheral wells contained: (1) anti IgM; (2) anti kappa light chains; (3) anti IgG; (4) anti lambda light chains; (5) anti $\lg A$; (6) anti lambda light chains.

Radioactive precipitin lines formed by interaction of labelled IgM with antiserum to IgM and antiserum to kappa light chains showed a pattern of complete identity. 
Table Serum and synovial fluid rheumatoid factor activities and immunoglobulin levels

\begin{tabular}{|c|c|c|c|}
\hline \multirow[t]{3}{*}{ Patient No. } & \multirow[t]{3}{*}{ Diagnosis } & \multicolumn{2}{|c|}{ Rheumatoid fac } \\
\hline & & Serum & \\
\hline & & Latex & $S S C_{\ddagger}^{+}$ \\
\hline 1 & Rheumatoid arthritis & 5120 & 128 \\
\hline 2 & Rheumatoid arthritis & 80 & $\mathbf{0}$ \\
\hline 3 & Rheumatoid arthritis & 80 & $\mathbf{0}$ \\
\hline 4 & Psoriatic arthropathy & 0 & $\mathbf{0}$ \\
\hline 5 & Traumatic synovitis & 0 & $\mathbf{0}$ \\
\hline
\end{tabular}

*Expressed as reciprocal of titre.

\section{Patient studies}

The antiglobulin titres and immunoglobulin levels in the sera and synovial fluids of the five patients with joint disease are shown in the Table. Only one of the three sero-positive rheumatoid patients (Case 1) had antiglobulin activity in the synovial fluid. Serum immunoglobulin levels were normal in all subjects except for the patient with psoriatic arthropathy (Case 4) who had a selective absence of serum IgA with normal IgG and IgM levels; one rheumatoid patient (Case 2) had a raised serum IgA level.

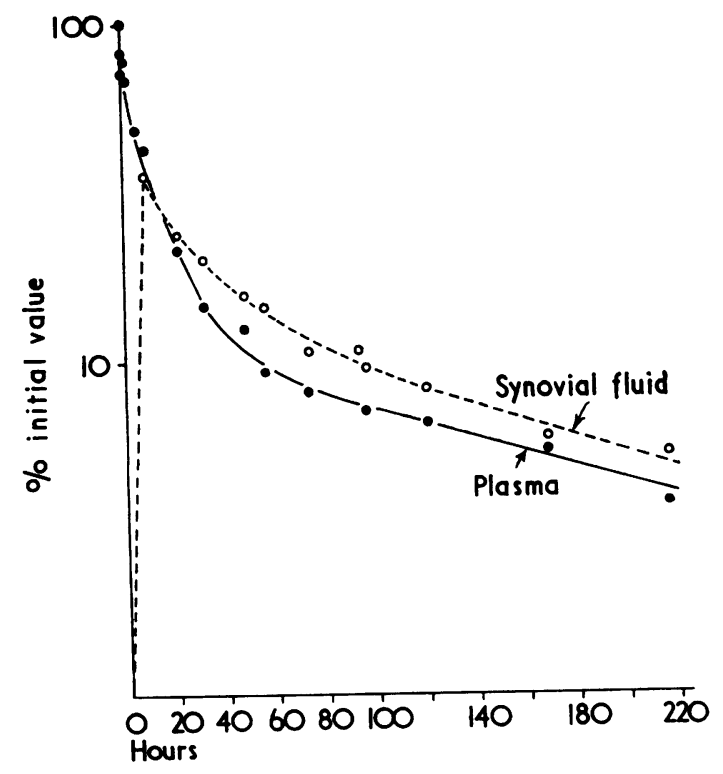

FIG. 3 Plasma-synovial fluid transport (Patient 5). Specific activities plotted as a percentage of the 15-min. plasma activity against time in hours.

Plasma activity fell rapidly at first followed by a slower constant linear fall.

Synovial fluid activity rose rapidly to a peak, and then declined in parallel with the plasma activity.
Immunoglobulin levels ( $\mathrm{mg} . / 100 \mathrm{ml}$.)

\begin{tabular}{|c|c|c|c|c|c|}
\hline \multicolumn{3}{|c|}{ Serum } & \multicolumn{3}{|c|}{ Synovial fluid } \\
\hline$I g G$ & $\operatorname{Ig} A$ & $I g M$ & $I g G$ & $\operatorname{Ig} A$ & IgM \\
\hline 860 & 174 & 43 & 430 & 105 & 13 \\
\hline 1680 & 440 & 72 & 1050 & 165 & 10 \\
\hline 1200 & 142 & 70 & 670 & 96 & 27 \\
\hline 00 & 0 & 58 & 1650 & 0 & 23 \\
\hline 760 & 148 & 135 & 840 & 120 & 100 \\
\hline
\end{tabular}

tSensitized sheep cell agglutination test.

\section{PLASMA-SYNOVIAL FLUID TRANSPORT}

All six subjects showed similar results. After intravenous injection of the labelled antiglobulin, the plasma-specific activities fell in an exponential manner. A very rapid initial fall to 20 per cent. of the 15-min. plasma level occurred within 26 to $42 \mathrm{hrs}$ in all subjects, indicating rapid catabolism and/or equilibration with the extravascular space (Figs 3, 4, and 5). Equilibrium between the plasma and synovial compartments was established at 72 to $108 \mathrm{hrs}$ and was followed by much slower linear declines of plasma activities, suggesting slower constant rates of IgM catabolism. At all points tested on the plasma curves, the sample activities approximated 90 per cent. TCA-precipitability.

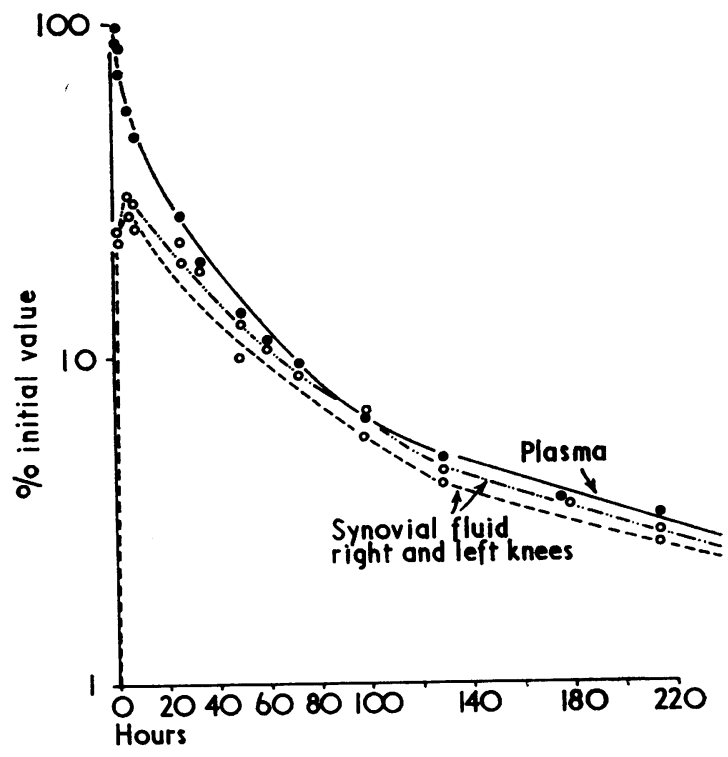

FIG. 4 Plasma-synovial fluid transport (Patient 4). Specific activity curves similar to those shown in Fig. 3. Values almost identical in each knee joint. 


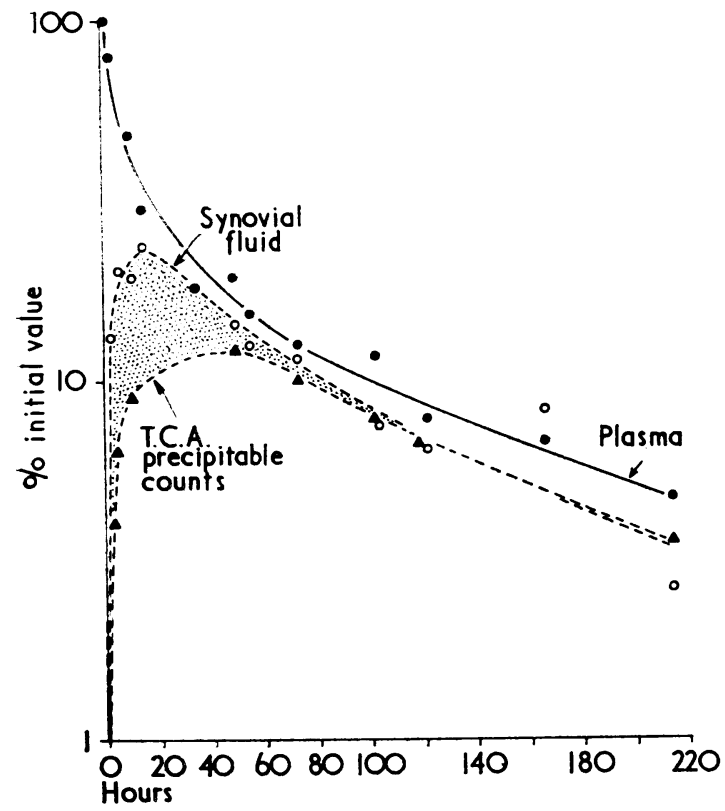

FIG. 5 Plasma-synovial fluid transport (Patient 2). Specific activity curves similar to those shown in Figs 3 and 4. Synovial fluid curve replotted as percentage of TCAprecipitable counts. Hatched-in area represents free ${ }^{125 I}$ released from labelled $R F$ within the joint.

After intravenous injection, synovial fluid activities rose rapidly, reaching peaks of 17 to 35 per cent. of the 15-min. plasma level by 5 to $24 \mathrm{hrs}$. Levels then declined in parallel with the plasma activity; in all cases, the slope of the falls showed an initial steep component. In three patients, synovial sample activities were higher than the corresponding plasma samples once equilibrium between synovial fluid and plasma was established (Fig. 3). The samples from two joints in the same patient showed almost identical activities (Fig. 4). The radioactivity in the samples from the rapidly rising and steeply declining points on the synovial fluid curves were 21 to 70 per cent. TCA-precipitable; those from the later points (slowly declining in parallel with plasma activity) were 75 to 100 per cent. TCA-precipitable (Fig. 6).

At all times during the study, free radio-iodine was detected in the subjects' urine in amounts compatible with the catabolism of the labelled IgM, the bulk being detected within the first $24 \mathrm{hrs}$.

\section{SYNOVIAL FLUID-PLASMA TRANSPORT}

After the intra-articular injection of the labelled RF, a steep nearly linear decline of activity was seen in the synovial fluid of the injected (left) joints in three patients; the activities decreased to 10 per cent. of that in the $30-\mathrm{min}$. synovial fluid samples within 20

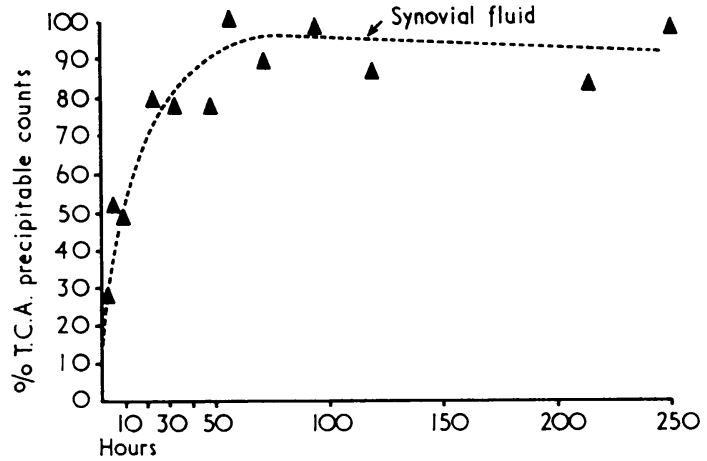

FIG. 6 Plasma-synovial fluid transport (Patient 3). TCA-precipitability of synovial fluid activity. The initial low levels of TCA-precipitability are thought to reflect the free label liberated by destruction of avid $R F$ within the joint. The higher subsequent levels reflect the label still bound to less avid antiglobulin circulating in equilibrium between plasma and synovial fluid.

to $38 \mathrm{hrs}$ (Fig. 7). The fourth patient had a slower decline, reaching 10 per cent. in $100 \mathrm{hrs}$. All sample activities tested were 90 to 97 per cent. TCA-precipitable.

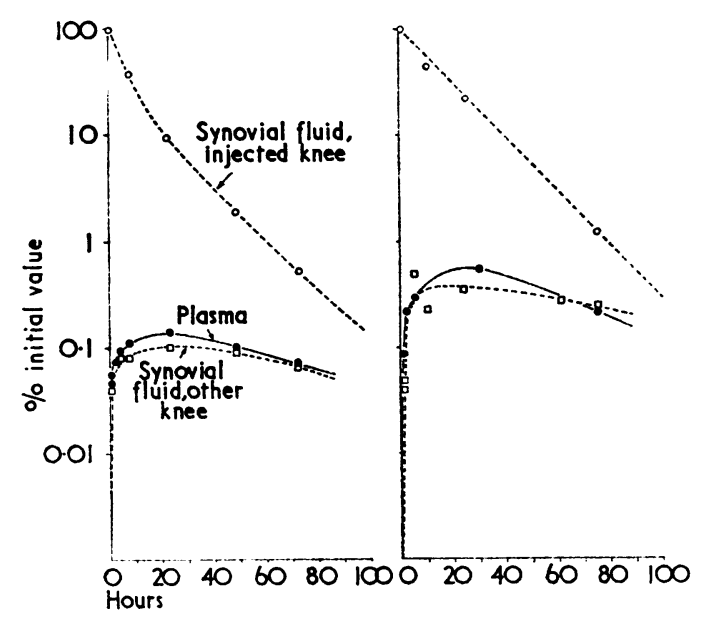

FIG. 7 Synovial fluid-plasma transport (Patient 4 on left, 2 on right ). Specific activities plotted as a percentage of the 30-min. injected-joint synovial fluid activity.

Synovial fluid activities in the injected joint fell in a rapid near linear fashion.

Activities in plasma and in synovial fluid from the contralateral joint rose quickly to peaks, and then declined gradually in parallel with one another.

In the four patients studied, plasma activities rose rapidly, and within 24 to $40 \mathrm{hrs}$ reached peaks of $0 \cdot 1$ to 0.5 per cent. of the radioactivity present in the 30-min. synovial fluid sample. The plasma activities then fell more slowly than the synovial fluid activities in the injected joint. Synovial fluid activities from the 
non-injected (right) knees showed levels nearly identical to those of the plasma (Fig. 7). All the plasma and non-injected joint samples tested approached 70 per cent. TCA-precipitability.

\section{AUTORADIOGRAPHY}

The autoradiographs performed on sections of rheumatoid synovial membrane removed 4 days after intra-articular injection of labelled RF demonstrated intracellular radioactivity of fixed tissue mononuclear cells (Fig. 8).

\section{Summary of transport data}

After intravenous injection of the labelled rheumatoid factor (RF), plasma specific activity fell very rapidly at first and then showed a slower linear rate of fall. The antiglobulin rapidly entered the synovial fluid, equilibrated, and fell in parallel with the plasma levels. When the RF was injected directly into a joint, the specific activity in that synovial fluid fell in a rapid and near linear fashion. The labelled RF rapidly entered the plasma and the contralateral (non-injected) knee joint, where activities quickly reached peaks and then slowly declined in parallel at constant linear rates.

\section{Discussion}

Although the purified IgM used in this study contained only kappa type light chains, it appeared to consist of a heterogeneous population of antiglobulins. The biological heterogeneity of the IgM was illustrated by its behaviour in vitro during the isolation procedure, and by its subsequent activity in vivo. When the IgG-IgM cryoglobulin was chromatographed at pH 4.6, the IgM remained in part bound to IgG; gel filtration at $\mathrm{pH} 3 \cdot 0$, however, gave a complete separation of IgG and IgM components. Furthermore, on a mg. per mg. basis, the IgM separated at $\mathrm{pH} 3.0$ had a higher antiglobulin titre $(1: 10,240)$ than the IgM obtained at pH 4.6 (1: $1,280)$. The ability of the strongly acidic buffer to elute the more avid antibody is an indication of biologic heterogeneity among IgM antiglobulin molecules (Allen and Kunkel, 1966), and similar heterogeneity has previously been demonstrated for RF present in the sera of patients with rheumatoid arthritis (Williams and Kunkel, 1963; Franklin and Fudenberg, 1965). Thus, the labelled IgM appeared to contain a heterogeneous population of antiglobulins which differed in their avidity for IgG.

After the intravenous injection of the labelled IgM, much of the more avid population of antiglobulin molecules presumably formed large tightlybound complexes with circulating IgG; these immune complexes would be rapidly sequestered and destroyed by the systemic reticulo-endothelial system or elsewhere. These events were thought to be reflected in the initial steep decline of the plasmaspecific activity and by the early appearance of

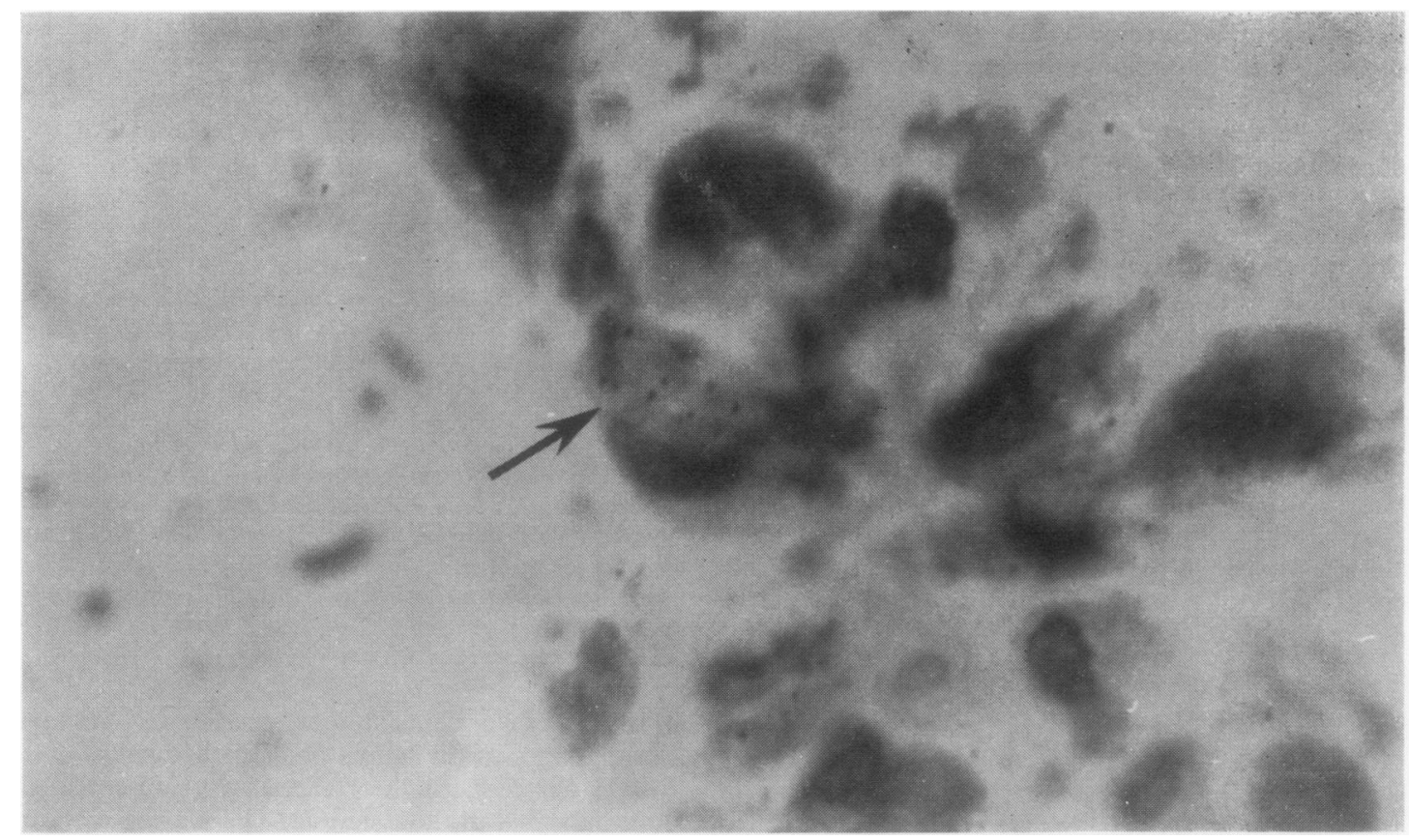

FIG. 8 Rheumatoid synovial membrane from Patient 3, showing intracellular radioactivity in tissue mononuclear cells. $\times 1,000$. 
abundant free iodine in the urine. Similarly shaped serum decay curves for circulating immune complexes have previously been described (Strober, Wochner, Barlow, McFarlin, and Waldmann, 1968). The less avid population of the injected antiglobulin presumably formed smaller or less tightly bound complexes with IgG and was catabolized at a slower constant rate, as reflected in the second part of the plasma activity curves. A dynamic equilibrium between RF and denatured IgG has previously been demonstrated in vitro (Aho and Simons, 1963); a similar equilibrium may have existed between the plasma IgG and the less avid labelled antiglobulin in vivo. Both the avid and less avid RF readily traversed the synovial membrane. However, the avid RF appeared to be rapidly sequestered and destroyed within the joint space, whereas the less avid RF equilibrated between the plasma and synovial compartments. These events were illustrated by the initial steep fall of the synovial curves and by their subsequent gradual decline, which paralleled the plasma curves.

Another explanation for the rapid initial catabolism of the labelled material would be the presence of significant amounts of denatured IgM in our preparation. This seems unlikely, however, for several reasons. First, the injected IgM retained its biological activity as demonstrated by its antiglobulin titre of $1: 1,280$ at a concentration of $0.6 \mathrm{mg} . / \mathrm{ml}$. Further evidence for intact biological activity was the cryoprecipitation of 80 per cent. of the labelled IgM when exposed to normal IgG at $4^{\circ} \mathrm{C}$. for $12 \mathrm{hrs}$. Secondly, when the IgM content of our preparation was measured by quantitative complement-fixation, a smooth-shaped curve was obtained and no anticomplementary activity was present. This indicated that the material contained no aggregated IgM.

The rapid near linear fall in synovial fluid activity and the immediate rapid rise in plasma activity after the intra-articular injection of the labelled antiglobulin demonstrate the ease with which RF crosses the synovial membrane. The fact that these synovial samples contained mainly TCA-precipitable counts does not exclude significant sequestration of antiglobulin within the joint. Although only 5 to 10 per cent. of the counts were non-TCA-precipitable, this may represent a considerable amount of sequestered antibody. The initial dose injected intra-articularly was very large, particularly when confined to the relatively restricted synovial space. Indeed, it is likely that much of the more avid RF was immediately trapped and destroyed within the joint. This would explain the failure to observe an initial steep decline in the curves of both the plasma and contralateral synovial fluid after intra-articular injection of the labelled RF. It is possible, however, that the more avid RF did enter the circulation, and that its catabolism was masked by the slow entry of the anti- globulin into the large plasma compartment.

A similar experiment, using a labelled IgM cold agglutinin, was recently performed in patients with rheumatoid arthritis (Brown and others, 1968). After intravenous administration of the IgM, the plasmaspecific activities fell in an exponential manner; no steep component was observed and equilibration between intra- and extravascular compartments was reached by 20 to $120 \mathrm{hrs}$. Plasma catabolism of the IgM then proceeded at constant fractional rates. Synovial fluid activities rose gradually and then fell in parallel with the plasma curves, indicating a dynamic equilibrium between plasma and joint IgM. The less avid population of our labelled antiglobulin behaved in a manner similar to the IgM cold agglutinin. This can be illustrated by comparing the total synovial fluid radioactivity (after intravenous administration of labelled IgM) with the percentage of activity which was TCA-precipitable (Fig. 5). The lower synovial curve ( $\Delta----\Delta)$ reflects the behaviour of the less avid antibody, and the hatched-in area was considered to represent free iodine released from avid antibody which had been complexed, sequestered, and broken down within the synovial space.

Several observations suggested that some of the extravascular sequestration of labelled RF occurred within the inflamed joints. First, synovial fluido activities reached their peaks while the plasmaspecific activities were falling, suggesting synovial trapping of intravenously-injected antiglobulin. Secondly, the synovial fluid activities showed an initial sharp fall which paralleled the steeply declining part of the plasma curves; this was thought to reflect synovial complexing and removal of the more avid RF molecules. Thirdly, the free iodine present in the initial synovial fluid samples (non-TCAprecipitable activity) persisted for up to $48 \mathrm{hrs}$ and accounted for as much as $\mathbf{8 0}$ per cent. of total counts. Since 98 per cent. of the $125 \mathrm{I}$ was shown to be attached to the IgM before injection, the presence and persistence of free iodine within the joint strongly suggested synovial destruction of the labelled antiglobulin. Indeed, the rheumatoid joint has been shown to be a rich source of denatured IgG (Hannestad, 1967), the specific antigen for the labelled antiglobulin. In the present study, the behaviour of the RF was nearly identical in the patients with rheumatoid, psoriatic, or traumatic arthritis, suggesting that denatured IgG may exist in any inflamed joint. It would seem, therefore, that the inflamed synovium, irrespective of the underlying disease, can remove and destroy circulating avid RF. The concept of RF sequestration within joints is well established. Previous studies in rheumatoid patients have demonstrated IgG-IgM complexes within synovial fluid white cells from which free RF can be eluted (Astorga and Bollet, 1965). In this study, the autoradiographs of the synovial membrane, showing radioactivity 
within fixed tissue mononuclear cells, further suggest antiglobulin sequestration by the synovial reticuloendothelial system.

The ability of the inflamed synovial space rapidly to complex and sequester the more avid RF would suggest that the RF detectable in synovial fluid by conventional techniques depends primarily on the presence of less avid RF. In contrast, the ability of less avid RF to equilibrate freely across the synovial membrane would permit a concentration gradient to develop in favour of the plasma. Thus, the contribution of serum RF to the synovial pool of detectable RF appears to depend on the amount of less avid serum RF.

The synovial sequestration of RF may be responsible for the depression of synovial fluid complement in patients with rheumatoid arthritis (Hedberg, 1964; Pekin and Zvaifler, 1964). Assuming that the interaction of more avid RF with IgG leads to complement utilization (Davis, 1966; Fish, Michael, Gewurz and Good, 1966), the presence of predominantly avid RF might explain in part the depression of synovial fluid complement in rheumatoid patients whose synovial fluid contains no detectable RF. Avid RF which is rapidly bound and sequestered would not be detected by conventional techniques.

\section{Summary}

Catabolism and serum-synovial transport of a purified rheumatoid factor (RF) were studied in five patients with inflammatory joint disease. The RF isolated from a mixed (IgG-IgM) cryoglobulin con- tained a heterogeneous population of antiglobulins which differed in their avidity for IgG. After intravenous administration, the more avid RF presumably complexed to IgG and these immune complexes were rapidly eliminated from the circulation. The less avid RF equilibrated freely between the plasma and synovial compartments and was catabolized slowly. Both the avid and less avid RF traversed the synovial membrane; however, the avid RF was rapidly eliminated within the synovial space. After intra-articular injection, the less avid RF quickly appeared in the plasma and in the noninjected joints, whereas the more avid RF was apparently sequestered within the injected joints. These observations suggest:

(a) that immune elimination of avid RF occurs within the plasma and synovial spaces,

(b) that the synovial membrane offers no barrier to antiglobulin transport,

(c) that the contribution of serum RF to the synovial pool of detectable RF depends mainly on the amount of less avid RF present in serum.

We gratefully acknowledge Miss Jo Ellen Cunningham and Miss Mary Baker for their valuable technical assistance, Dr. Amiel Cooper for the IgM labelling, and Dr. Hans L. Spiegelberg for helpful discussion.

Dr. R. Bluestone is a Travelling Fellow of the Arthritis and Rheumatism Council of Great Britain and holder of a Wellcome Research Travel Grant, Dr. A. Cracchiolo is a Giannini Foundation Fellow, and Dr. L. S. Goldberg a Clinical Investigator of the Veterans Administration.

This study was in part supported by USPHS grant nos. GM 15759 and RR 00238, and by a Clinical Investigatorship from the Veterans Administration (15-69).

\section{References}

Ahlström, S., Gedda, P. O., AND Hedberg, H. (1956) Acta rheum. scand., 2, 129 (Disappearance of radioactive serum albumin from joints in rheumatoid arthritis).

Aнo, K., AND Simons, K. (1963) Arthr. and Rheum., 6, 676 (Studies of the antibody nature of the rheumatoid factor. Reaction of the rheumatoid factor with human specific precipitates and with native human gamma globulin).

Allen, J. C., AND Kunkel, H. G. (1966) Ibid., 9, 758 (Hidden rheumatoid factors with specificity for native $\gamma$-globulins).

AstoRGA, G., AND Bollet, A. J. (1965). Ibid., 8, 511 (Diagnostic specificity and possible pathogenetic significance of inclusions in synovial leucocytes).

Benacerraf, B., Sebestyen, M., AND CoOper, N. S. (1959). J. Immunol., 82, 131 (The clearance of antigen antibody complexes from the blood by the reticulo-endothelial system).

Bland, J. H., and Clark, L. (1963) Ann. intern. Med., 58, 829 (Rheumatoid factor in serum and joint fluid).

Brown, D. L., Cooper, A. G., and Bluestone, R. (1968) Arthr. and Rheum., 11, 818 (Metabolism and synovial transport of iodinated IgM and albumin in rheumatoid arthritis). [Abstract.]

Condemi, J. J., Barnett, E. V., Atwater, E. C., Jacox, R. F., Mongan, E. S., and Vaughan, J. H. (1965). Ibid., 8, 1080 (The significance of antinuclear factors in rheumatoid arthritis).

DAvis, J. S. (1966). Ibid., 9, 631 (A hypothetical common mechanism in systemic lupus erythematosus and rheumatoid arthritis).

Feinendegen, L. E., AND Bond, V. P. (1962) Exp. Cell Res., 27, 474 (Differential uptake of ${ }^{3}$ H-thymidine into the soluble fraction of single bone marrow cells, determined by autoradiography).

Fish, A. J., Michael, A. F., Gewurz, H., AND Good, R. A. (1966) Arthr. and Rheum., 9, 267 (Immunopathologic changes in rheumatoid arthritis synovium). 
Franklin, E. C., AND Fudenderg, H. H. (1965) Ann. N.Y. Acad. Sci., 124, 873 (The heterogeneity of rheumatoid factors and the genetic control of polypeptide chains of $\gamma$-globulins).

GoldberG, L. S., AND BARNETT, E. V. (1967) J. Immunol., 99, 803 (Mixed $\gamma$ G- $\gamma$ M cold agglutinin).

HANNESTAD, K. (1967) Clin exp. Immunol., 2, 511 (Presence of aggregated $\gamma$ G-globulin in certain rheumatoid synovial effusions).

- AND Mellbye, O. J. (1967) Ibid., 2, 501 (Rheumatoid factor in synovial effusions: local production and consumption).

Hedberg, H. (1964) Acta rheum. scand., 10, 109 (The depressed synovial complement activity in adult and juvenile rheumatoid arthritis).

Helmkamp, R. W., Contreras, M. A., and Bale, W. F. (1967) Int. J. appl. Radiat., 18, 737 (131-labeling of proteins by the iodine monochloride method).

Lowry, O. H., Rosebrough, N. J., Farr, A. L., and Randall, R. J. (1951) J. biol. Chem., 193, 265 (Protein measurement with the Folin phenol reagent).

MACKIEWICZ, S., AND FENRYCH, W. (1961). Ann. rheum. Dis., 20, 265 (Immunoelectrophoretic analysis of proteins in serum and synovial fluid in rheumatoid arthritis and ankylosing spondylitis).

McFARLANE, A. S. (1963) J. clin. Invest., 42, 346 (In vivo behavior of $\mathrm{I}^{131}$-fibrinogen).

Pekin, T. J., ANd Zvaifler, N. J. (1964) Ibid., 43, 1372 (Hemolytic complement in synovial fluid).

Rodnan, G. P., Eisenbeis, C. H., and Creighton, A. S. (1963) Amer. J. Med., 35, 182 (The occurrence of rheumatoid factor in synovial fluid).

- AND Maclachlan, M. J. (1960) Arthr. and Rheum., 3, 152 (The absorption of serum albumin and gamma globulin from the knee joint of man and rabbit).

SChUR, P. H., AND SANDSON, J. (1963) Ibid., 6, 115 (Immunologic studies of the proteins of human synovial fluid).

Strober, W., Wochner, R. D., Barlow, M. H., McFarlin, D. E., and WaldmanN, T. A. (1968). J. clin. Invest., 47, 1905 (Immunoglobulin metabolism in ataxia telangiectasia).

Vaughan, J. H., AND Butler, V. P. (1962). Ann. intern. Med., 56, 1 (Current status of the rheumatoid factor).

Wasserman, E., AND LeVINE, L. (1961). J. Immunol., 87, 290 (Quantitative micro-complement fixation and its use in the study of antigenic structure by specific antigen-antibody inhibition).

Williams, R. C., AND Kunkel, H. G. (1963). Arthr. and Rheum., 6, 665 (Separation of rheumatoid factors of different specificities using columns conjugated with gamma-globulin).

\section{RÉSUMÉ}

Le catabolisme et le transport synovial du facteur rhumatoide

Le catabolisme et le transport séro-synovial du facteur rhumatoïde purifié (FR) ont été étudié chez cinq malades atteints de maladies inflammatoires affectant les articulations. Le FR isolé de cryoglobuline (IgG-IgM) contenait une population hétérogène d'antiglobulines qui étaient différentes dans leur avidité pour l'IgG. Après l'administration intraveineuse le plus avide FR probablement formait complexe avec IgG et les complexes immuns étaient rapidement éliminés de la circulation. Les moins avides FR s'équilibraient librement entre le plasma et les compartiments synoviaux et le catabolisme avait lieu lentement. Les plus avides ainsi que les moins avides FR traversaient la membrane synoviale; cependant le FR avide était éliminé rapidement de l'espace synovial. Après l'injection intra-articulaire, les FR moins avides apparaissaient rapidement dans le plasma et dans les articulations non-injectées, tandis que les FR plus avides étaient apparémment séquestrés à l'interiéur des articulations injectées.

Ces observations suggèrent que:

(a) l'élimination immune du FR avide a lieu dans le plasma et l'espace synovial,

(b) la membrane synoviale n'offre pas de barrière au transport de l'antiglobuline.

(c) la contribution du RF sérique au 'pool' synovial de RF discernable dépend principalement de la quantité de FR moins avide présent dans le sérum.

\section{SUMARIO}

\section{Catabolismo y transporte sinovial del factor reumatoide}

El catabolismo y el transporte serosinovial de un factor reumatoide (FR) purificado fueron estudiados en cinco pacientes con enfermedad articular inflamatoria. El FR aislado de una mezcla de crioglobulina (IgG-IgM) contenía una población heterogénea de antiglobulinas que diferían en su avidez por el IgG. Al cabo de administración intravenosa, el FR más ávido probablemente se unió al IgG y estos complejos inmunes fueron eliminados rápidamente de la circulación. El FR menos ávido se equilibró libremente entre el plasma y los compartimientos sinoviales y fue catabolizado lentamente. Los dos factores reumatoides, el ávido y el menos ávido, atravesaron la membrana sinovial; no obstante, el FR ávido fue rápidmente eliminado dentro del espacio sinovial. Al cabo de inyección intraarticular, el FR menos ávido apareció prontamente en el plasma y en las articulaciones que no habian sido inyectadas, en tanto el FR más ávido fue retenido dentro de las articulaciones inyectadas. Estas observaciones sugieren que

(a) la eliminación inmune de FR ávido ocurre dentro del plasma y los espacios sinoviales,

(b) la membrana sinovial no ofrece ninguna barrera al transporte de antiglobulina,

(c) el aporte del FR sérico al 'pool' sinovial de FR detectable depende principalmente de la cantidad de FR menos ávido presente en el suero. 